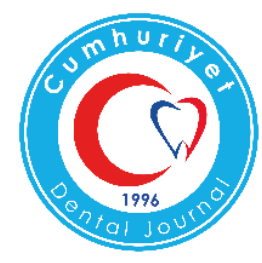

\title{
EVALUATION OF TEMPERATURE CHANGES IN THE PULPAL CHAMBER OF THE PRIMARY TOOTH DURING CURING OF COLORED COMPOMERS
}

\author{
Renkli Kompomerlerin Sertleşmesi Sırasinda Süt Dişi Pulpa Odasında Görülen \\ Sicaklık Değişimlerin Değerlendirilmesi
}

Halenur ALTAN ${ }^{1}$, Zeynep GOZTAS ${ }^{2}$, Gul TOSUN ${ }^{3}$, Tuğrul SARI ${ }^{4}$

\begin{tabular}{ll} 
Makale Kodu/Article Code & $: 403044$ \\
Makale Gönderilme Tarihi & $: 07.03 .2018$ \\
Kabul Tarihi & $: 28.05 .2018$ \\
\hline
\end{tabular}

\section{ABSTRACT}

Purpose: To investigate the temperature changes in the primary teeth pulp chambers during the curing of different colored compomers

Materials and Methods: Class II cavities were prepared in primary mandibular second molars $(n=5)$. Gold, blue, green, berry, and tooth (control group) colored compomers were tested in two steps (aproximal and occlusal). Measurement of pulp chamber temperature changes during curing was performed with a $\mathrm{J}$ type thermocouple. The data including differences between the highest and initial temperature values were recorded and analyzed by two-way ANOVA and Mann-Whitney U tests

Results: There were statistically significant differences temperature changes in groups $(\mathrm{p}<0.05)$. Cümle yeniden kurulabilir. Gold colored compomer Demonstrate the highest temperature increase in both proximal and occlusal surfaces. Tooth colored compomer (A2) Demonstrate the lower temperature increase. The temperature increase in aproximal cavities was found higher than the temperature increase in occlusal cavities.

Conclusions: Colored compomer can be an alternative restorative materials in superficial class I and II cavities in primary teeth. Dark coloured compomers should be used in deep cavities.

Running Title: Temperature Changes During Curing of Colored Compomers

Key Words: Colored, Compomer, Temperature rise

\section{öz}

Amaç: Farklı renkli kompomerlerin 1şıkla sertleşimesi sırasında süt dişi pulpa odasındaki sıcaklık değişikliklerin araştırılması amaçlanmaktadır.

Materyal ve Metod: İkinci molar süt dişleri Sınıf II kaviteler hazırlandı ( $\mathrm{n}=5)$. Altın sarısı, mavi, yeşil, mor ve diş rengindeki kompomerler iki aşamada (aproksimal ve oklüzal) test edildi. Işıkla sertleşme sırasında meydana gelen pulpa odasındaki sıcaklık değişimi ölçümleri J tipi termokupl ile gerçekleştirilmiştir. En yüksek sıcaklık ve başlangıç sıcaklıkları arasındaki farklar veri olarak kaydedildi ve analizleri iki yönlü-ANOVA ve MannWhitney U testi ile yapıldı.

Results: Sicaklık değişimleri arasında istatiksel olarak anlamlı farklar vardı $(\mathrm{p}<0.05)$. Altın sarısı kompomer, hem aproksimal hem de oklüzal yüzeylerde en yüksek sıcaklık artışını gösterdi. Diş rengi (A2) en düşük sıcaklık artışını gösterdi. Aproksimal kavitedeki sıcaklık artışı oklüzal kavitedeki artıştan daha yüksek bulunmuştur.

Sonuç: Renkli kompomerler süt dişlerinde sığ sınıf I ve sinıf II kavitelerde alternatif restoratif materyal olabilir.

Kısa başlık: Renkli Kompomerlerin Sertleşmesi Sırasındaki Sıcaklık Değişimleri

Anahtar Kelimeler: Renkli, Kompomer, Sıcaklık artış1

\footnotetext{
${ }^{1}$ Department of Pediatric Dentistry, Gaziosmanpasa University, Tokat, Turkey

${ }^{2}$ Private Dentist, Ankara, Turkey

${ }^{3}$ Department of Pediatric Dentistry, University of Selcuk, Konya, Turkey

${ }^{4}$ Private Dentist, Istanbul, Turkey
} 


\section{INTRODUCTION}

Compomers (polyacid modified composite resins) are very popular restorative materials in primary dentition. ${ }^{1}$ Compomers are a mixture of glass ionomer cements and resin-based composites, containing polyacid modified monomers with fluoride-releasing silicate glasses, resin components, photoinitiators, and stabilizers. $^{2}$ Due to their preservation of dental structure in cavity preparation, relatively low thermal conductivity, fluoride release, continuous progress in the stability of the composition, and an increasing demand of parents to provide esthetic restorations for their children, compomers are well-received. ${ }^{1,3}$ Colored compomer (CC) has been commercialized for use in children's dentistry and to improve their cooperation in dental treatments. $^{4}$

$\mathrm{CC}$ is produced by adding glitter particles and coloring pigments to conventional compomers to create different colors (e.g., blue, green, pink, and gold), and the filler content is similar to conventional compomers. ${ }^{4}$ As with conventional compomers, CCs are similar to traditional composites in that their setting reaction includes light-curing. Compomers and CCs contain the light-activated ingredient dimethacrylate. Typically light-initiated camphorquinone with an amine accelerator is sensitive to blue light at $470 \mathrm{~nm}$ and 7,8 MK as the initiator. ${ }^{5}$ Different light devices of varying power outputs are used during the curing of compomers. The factors that can affect the temperature changes in the pulp chamber are the light source type, intensity, and activation time..$^{4-6}$ For curing the compomers, the most common type of visible light activation unit uses blue light-emitting diodes (LEDs). ${ }^{7}$ Highintensity LEDs were introduced to reduce the curing time for sufficient polymerization, with $1400 \mathrm{~mW} / \mathrm{cm}^{2}$ and $395-480 \mathrm{~nm}$ for 40 seconds. ${ }^{7,8}$

The pulp has a structure that is affected by physical, chemical, biological and thermal stimuli. Several factors can affect the temperature increase in the pulp chamber, such as cavity preparation procedures, bleaching, polishing of dental restorations, laser applications, polymerization of light-cured materials. ${ }^{9-11}$ Thermal cameras and thermocouples are used to evaluate a temperature increase in the pulp. ${ }^{9}$ Thermal cameras are devices that display images in different colors according to the temperature of the region that the camera focuses on, by sensing the infrared wavelengths caused by thermal energy. Regarding the use of thermal camera, thermocouples are used in evaluating the temperature increase in the pulp chamber as the temperature change on the tooth surfaces is evaluated. ${ }^{9,12}$ The pulpal microcirculation occurring in the pulp plays an important role as a coolant in decreasing the effect of thermal stimuli on the pulpal tissue. ${ }^{13}$ In their study on monkeys, Zach and Cohen ${ }^{14}$ found that a temperature increase of $5.5^{\circ} \mathrm{C}$ in the pulp chamber for 10 seconds led to the loss of vitality on the pulp tissue by $15 \%$.

Many studies have demonstrated the physical, mechanical and biological properties of CCs. ${ }^{15-18}$ To date, few studies have been carried out to measure the thermal properties of CCs. ${ }^{5,19-20}$ In this study, we investigated the temperature changes in a microcirculation model in the primary teeth pulp chamber for a class II cavity during the curing of different CCs. The null hypotheses in this study; there is no difference between the pulpal temperature changes during the curing of different CCs.

\section{MATERIALS AND METHODS}

The sample size was calculated at a $95 \%$ confidence interval and a significance level of 0.05 (tip I error), tip II error rate was 0.2 and effect size was 1.40 , according to the Savas et $a l .{ }^{20}$ The analysis indicated that a group sample size was $10(\mathrm{n}=10)$.

\section{Cavity Preparation}

Five extracted, caries-free, primary mandibular 
second molars were used in this study. The roots were removed $2 \mathrm{~mm}$ beneath the cementenamel junction. All organic remnants in the pulpal chambers were cleaned using a $5.25 \%$ sodium hypochlorite solution. The teeth were prepared as class II cavities. The cavity preparations were performed in two steps; aproximal box (only mesial) the occlusal cavity. A small diamond round (1/2 round) bur was used to remove the enamel on the occlusal surface. The diamond fissure bur was used to remove the dentin to a $4 \mathrm{~mm}$ depth of the aproximal box. The height $\mathrm{x}$ width $\mathrm{x}$ length dimensions of the cavity were $4 \times 3 \times 3$ (Figure 1). The angles of the walls and floors were slightly rounded. One millimeter of dentin remained between the pulp chamber, the axial wall and pulpal floor, measured with a caliper and assessed radiographically. The prepared teeth were kept in distilled water for protection from dehydration.

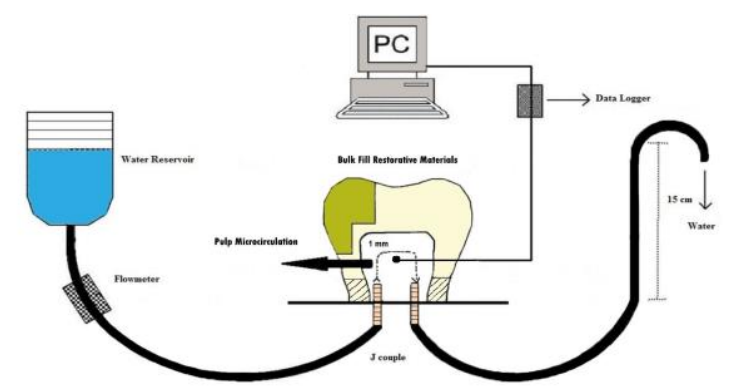

Figure 1. Dimensions of class II cavity in primary tooth

\section{Temperature changes in microcirculation model}

A pulpal microcirculation model, that originally designed by Savas et al. ${ }^{20}$ was used. The fluid flow rate of the system was set and kept constant at $1 \mathrm{ml} / \mathrm{min}$ using a digital infusion flowmeter (SK-600II infusion pump, SK Medical, Shenzhen, China). Distilled water at room temperature $(26 \circ \mathrm{C})$ was used to simulate blood and the blood pressure in the pulp at 15 $\mathrm{cm} \mathrm{H}_{2} \mathrm{O}$ (Figure 2). A heat-transfer unit (ILC P/N 213414; Wakefield Engineering, Beverly, MA) was applied to the tip of the thermocouple wire, fixed with light-curing glass ionomer cement (Calcimol LC; Voco GmbH, Cuxhaven, Germany) to maintain contact with the pulp chamber. Therefore, the gap around the thermocouple wire was sealed to prevent leakage from the system (Figure 2).

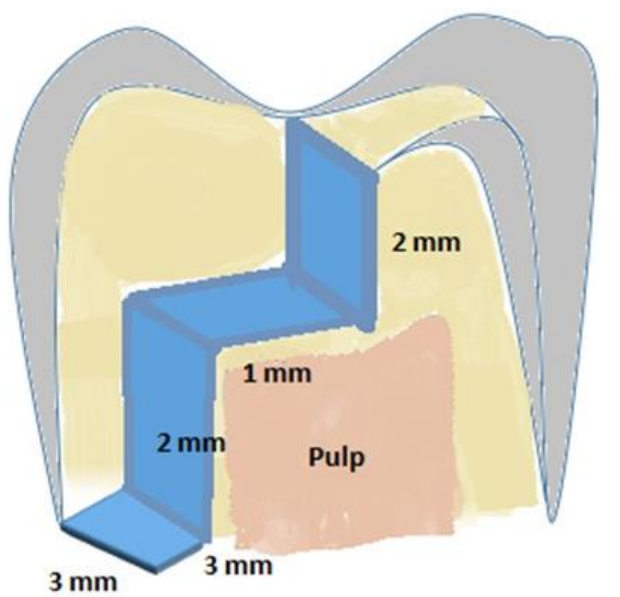

Figure 2. Schematic diagram of the measurement of intrapulpal temperature changes

Four different colors of Twinky Star (Voco, Cuxhaven, Germany) gold, blue, green, and berry compomers, as well as tooth-colored compomer (A2, DyractXtra, Densply) (control group) were tested in this study. The different compomers (gold, green, blue, berry, and toothcolored) were applied to the cavity in two steps. According to the manufacturers, the tooth colored compomer was cured for $20 \mathrm{~s}$ and the CCs for $40 \mathrm{~s}$. In the first step, a compomer was applied to the proximal cavity and cured with an LED curing unit (EliparFreelight, 3M ESPE, US) (Figure 2). In the second step, a compomer was applied to the occlusal cavity and cured. A $2 \mathrm{~mm}$ layer of compomer was placed on the floor of the proximal box. Acid etching or dentin bonding were not used before putting the compomers in the cavity. Two small notches were made at the edge of the proximal step and occlusal surface to remove the cured compomers from the tooth surface easily.

One tooth $(n=1)$ was used for each group randomly and 10 measurements were done for each teeth $(\mathrm{n}=10)$. During curing, the temperature was measured with a thermocouple connected to a data logger (XR440-M Pocket Logger, Pace Scientific, NC, USA) to record the temperature increase values from the pulp chamber during curing. The collected results in graphic form were monitored in real time and transferred to a computer. Later, the difference between the first and highest temperature values 
$(\Delta t)$ was calculated. The recorded data were analyzed by two-way ANOVA and MannWhitney U tests. A Kruskall Wallis analysis was used to conduct multiple comparisons of the groups to determine their differences.

\section{RESULTS}

The mean pulp temperature increase values and the standard deviations are shown in Table 1. The two-way ANOVA indicated that both the tested groups $(\mathrm{p}=0.05)$ and the proximal and occlusal cavities $(p=0.010)$ significantly influenced the intrapulpal temperature. The highest temperature increase values in aproximal surface were recorded in the gold-colored group $\left(7,71^{\circ} \mathrm{C}\right)$, followed by the berry $\left(6,84^{\circ} \mathrm{C}\right)$, blue $\left(6,08^{\circ} \mathrm{C}\right)$, and green $\left(5,94^{\circ} \mathrm{C}\right)$ colored groups, and lastly the tooth colored-control group $\left(3.26^{\circ} \mathrm{C}\right)$. The highest temperature increase values in occlusal surface were recorded in gold-colored group $\left(5.79^{\circ} \mathrm{C}\right)$, followed by the blue $\left(4.16^{\circ} \mathrm{C}\right)$, green $\left(3.92^{\circ} \mathrm{C}\right)$, and berry $\left(5,94^{\circ} \mathrm{C}\right)$, and tooth colored groups (2.34).

Table 1. Mean values and standart deviations of mean temperature changes of the groups

\begin{tabular}{|l|l|l}
\hline Groups & $\begin{array}{l}\text { Aproximal Surface } \\
\text { Mean } \pm \text { SD }\end{array}$ & $\begin{array}{l}\text { Occlusal Surface } \\
\text { Mean } \pm \text { SD }\end{array}$ \\
\hline Gold & $7.71 \pm 1.30^{\mathrm{a}, *}$ & $5.79 \pm 1.01^{\mathrm{a}, * *}$ \\
\hline Green & $5.94 \pm 1.40^{\mathrm{b}, *}$ & $4.02 \pm 1.08^{\mathrm{b}, * *}$ \\
\hline Berry & $6.84 \pm 1.47^{\mathrm{b}, *}$ & $3.92 \pm 1.26^{\mathrm{b}, * *}$ \\
\hline Blue & $6.08 \pm 0.78^{\mathrm{b}, *}$ & $4.16 \pm 0.56^{\mathrm{b}, * *}$ \\
\hline $\begin{array}{l}\text { Tooth Colored } \\
\text { (Control Group) }\end{array}$ & $3.26 \pm 0.77^{\mathrm{c}, *}$ & $2.34 \pm 0.89^{\mathrm{c}, *}$ \\
\hline P & 0.001 & 0.001 \\
\hline
\end{tabular}

Different uppercase letters in each column indicate differences within the tested materials $(\mathrm{p}<0.05)$

Different stars in each row indicate differences within the tested materials $(\mathrm{p}<0.05)$

The lowest temperature increase values were recorded in the tooth-colored compomers. No significant differences in the temperature rise were observed for the berry, blue and green-colored groups ( $p>0.05)$. The Kruskall Wallis analysis revealed significant differences in the proximal and occlusal cavity applications $(\mathrm{p}<0.05)$, as shown in Table 1 . The temperature increases were higher in the aproximal cavity compared to occlusal cavity during polymerization for all compomer groups.

\section{DISCUSSION}

Compomers are widely used in pediatric dentistry and CCs. ${ }^{5}$ Even though CCs have similar contents with conventional compomers except color pigments and glitter particles. The temperature in the pulp chamber during the curing of CCs is not well known. There is no study in the literature regarding CCs that include thermal changes in primary dentition. The purpose of this study was to compare the temperature changes in the microcirculation model in primary teeth pulp chambers in class II cavities during the curing of different CCs.

Al-Qudah et $a l .{ }^{23}$ measured the temperature rise during the curing of resincontaining dental materials, flowable, packable, or conventional composites, compomers, and resin modified glass ionomers (RMGICs) with a thermal camera. The maximum temperature rise was observed in flowable composites, and minimum temperatures were observed in compomers and packable composites. Tosun et $a l .{ }^{24}$ compared the temperature rise under caries-affected and caries-unaffected primary tooth dentin during the curing of compomer and composite resin materials. As a result of the study, it was reported that there was no difference between the resin materials because both materials had high filler ratios (Compoglass F 77\% and Aelite LS 84\%). Kahvecioglu et $a .^{25}$ measured the thermal changes during the setting and curing of a glass carbomer, resin modified glass ionomer, and compomer in primary teeth. No difference in temperature increase was observed between compomer and RMGIC in occlusal cavities in primary teeth. The resin content (type, filler ratio, and size), color, monomer type, and ratio are important factors affecting temperature increase. $^{5}$

The twinky star CC contains Bis-GMA, diurethanedimethacrylate, TEGDMA, carboxylic acid modified methacrylate (TCB), silicon 
dioxide, and camphoroquinone. Twinky star has filler Barium aluminum fluoro borosilicate glass with dioxide particles and glimmer with a content of $77.8 \% \mathrm{w} / \mathrm{w} ; 60.8 \mathrm{v} / \mathrm{v}$, and a particle size of 0.4-3 $\mu \mathrm{m} .{ }^{18,20}$ Tooth colored compomer, Dyract Extra, contains Bis-GMA, urethane dimethacrylate (UDMA), TEGDMA, TCB and has filler $73 \% \mathrm{w} / \mathrm{w} ; 47 \mathrm{v} / \mathrm{v}$ with particle size 0,8 $\mu \mathrm{m}$. All tested compomers showed different temperature rises compared to tooth colored compomer, and the null hypothesis was rejected..$^{20}$ Despite the similar content in the filling materials, this difference in the temperature increase during the curing of compomers can be explained by the glitter effects.

Based on a study by Hwang et al. ${ }^{15}$, the distribution of light transmission can be affected by glittering; the gold color was noted to have a lower light transmission rate than the other colors (blue, green, pink, silver, orange, lemon, and tooth colored). Vandenbulcke et $a l .{ }^{19}$ reported that blue, green, and tooth CCs had greater curing depths (DoC) than other colors, and the gold color had the least DoC compared with the other colors. In the present study, the highest and lowest temperature increases were obtained in the gold $\left(7.71^{\circ} \mathrm{C}\right)$ and tooth colored $\left(3.26^{\circ} \mathrm{C}\right)$ compomers. The results of this study are partly consistent with those of the previous study; the blue and green CCs exhibited similar light transmissions. However, in relation to the highest light transmission in different CCs, there was no consensus in the literature. ${ }^{5,15,19}$ The studies showed that the transmission of light for the gold color was the least, and had a seemingly higher light absorption. ${ }^{15,19,26}$ The higher light absorption led to an increase in temperature during curing of the compomers with low light transmission.

Many factors of temperature changes in pulp can be connected with the contents of dental restorative materials, type of light curing unit (LCU), light intensity of the LCU, exposure time to LCU, and thickness of the remaining dentin. ${ }^{6,9,11}$ Different curing units (halogens, plasma arcs, and LEDs) were preferred to cure the composite resins and compomers. ${ }^{10,16}$ Contemporary LCUs are more commonly used than other light sources in restorative dentistry and have many benefits. For instance, they are resistant to overheating, have longer lifetimes, generate less heat, and their light output reduces minimally in time. ${ }^{22}$ In this study, same lightemiting diode was used to cure all samples so that the temperature increase of the compomers would not be affected by LCU factor.

Conventional compomers are widely used for class I and II cavities in anterior, and III, IV, and $\mathrm{V}$ cavities in posterior teeth. In deep cavities, the vitality of pulp tissue can be affected by thermal changes, especially in class II cavities. In this study, temperature increase in approximal cavities was higher than the occlusal cavities in in CCs, except for toothcolored compomer. Only the gold colored compomer was higher than the critical point of $5.5^{\circ} \mathrm{C}$, reported by Zach and Cohen. ${ }^{14}$ Blue and green exhibited similar temperature changes in aproximal and occlusal cavities. The difference between the occlusal and aproximal cavities may be explained by the orientation and number of dentine tubules in primary teeth. The number of dentine tubules increase when moving from the occlusal towards the aproximal wall and dentine tubules run oblique and parallel to the axial walls. ${ }^{27}$

There were some limitations of this present study; firstly, only one type light curing unit was used. Secondly, glitter particles in CCs were not evaluated. The temperature rise may be affected by the size and amount (per gram) of glitter particles. Thirdly, the temperature changes may be affected by the initial temperature in the pulp circulation model. The difference between the highest and initial temperature may be lower when the temperature in the pulp is close to body temperature. 


\section{CONCLUSION}

Glitter particles include irregular shapes and sizes in CCs that increase the temperature rise in primary teeth. The use of darker shades of compomers may be advisable, especially in deep cavities.

\section{REFERENCES}

1. Kramer N, Frankenberger R. Compomers in restorative therapy of children: A literature review. Int J Paediatr Dent 2007;17(1):2-9.

2. Mail P, Deshpand S, Single A. Microleakage of restorative materials: an in vitro study. $\mathrm{J}$ Indian Socpedoprev Dent. 2006;24(1):15-8.

3. McLean JW, Nicholson JW, Wilson AD. Proposed nomenclature for glass-ionomer dental cements and related materials. Quintessence Int 1994;25(9):587-589

4. Croll TP, Helpin ML, Donly KJ. Multicolored dual-cured compomer. Pediatr Dent 2004;26(3):273-276.

5. Atabek D, Bodur H, Kalayci S, Baygin O, Tirali E. Conversion degrees of a colored compomer in different colors utilized by various curing times. J Dent Child (Chic) 2011;78(2):83-87.

6. Hubbezoglu I, Unal M, Zan R, Hurmuzlu F. Temperature rises during application of er:Yag laser under different primary dentin thicknesses. Photomed Laser Surg 2013;31(5):201-05.

7. Oberholzer TG, Makofane ME, du Preez IC, George R, 2012. Modern high powered led curing lights and their effect on pulp chamber temperature of bulk and incrementally cured composite resin. Eur J Prosthodont Restor Dent 2012;20(2): 50 .

8. Soh MS, Yap AU, Siow KS. The effectiveness of cure of LED and halogen curing lights at varying cavity depths. Oper Dent 2003;28:707-15.

9. Aksakallı S, Demir A, Selek M, Taşdemir S. Temperature increase during orthodontic bonding with different curing units using an infrared camera. Acta Odontol Scand 2014;72(1):36-41.

10.Lefkowitz W, Robinson HBG, Postle HH. Pulpal response to cavity preparation. J Prosthet Dent 1958;8:315-24.

11.Smail SRJ, Patterson CJW, Mclundie AC. In vitro temperature rises during visible-light curing of a lining material and a posterior composite. J Oral Rehabil 1988;15:361-66.

12.Bouillaguet S, Caillot G, Forchelet J, Cattani-Lorente M, Wataha JC, Krejci L. Thermal risks from LED-and high-intensity QTH-curing units during polymerization of dental resins. J Biomed Mater Res B Appl Biomater, 2005;72(2): 260-67.

13. Sari T, Celik G, Usumez A. Temperature rise in pulp and gel during laser-activated bleaching: In vitro. Lasers Med Sci 2015;30(2):577-82.

14. Zach L, Cohen G. Pulp response to externally applied heat. Oral Surg Oral Med Oral Pathol 1965;19:515-30.

15.Hwang SW, Kwon TY, Kim KH, Kwon YH, Kim HI, Lee JB. Optical, mechanical, and chemical properties of colored compomer. Biomed Res 2007;11:36-42.

16. Avşar A, Tuloglu N. Effect of different topical fluoride applications on the surface roughness of a colored compomer. J Appl Oral Sci 2010;18(2):171-77.

17.Croll TP, Helpin ML, Donly KJ. Multicolored dual-cured compomer. Pediatr Dent 2004;26(3):273-76.

18. Arora V, Arora P, Srivastava N, Togoo RA. Multicoloured Restorations for Pediatric Dental Patients. Bri J Appl Sci Tech 2014;4(28): 4014.

19. Vandenbulcke JD, Marks LA, Martens LC, Verbeeck, RM. Comparison of curing depth of a colored polyacid-modified composite resin with different light-curing units. Quintessence Int 2010;41(9):87-94. 
20.Guler C, Keles A, Guler MS, Karagoz S, Cora ON, Keskin G. Thermal conductivity of different colored compomers. J Appl Biomater Funct Mater 2017 doi: 10.5301/jabfm.5000349.

21.Yan LJ, Chang P, Tian RH. A comprehensive evaluation of application of light-cured colored compomer for deciduous teeth. J Biol Regul Homeost Agents 2017;31(2): 439-445.

22. Savaş S, Botsalı MS, Küçükyılmaz E, Sarı T. Evaluation of temperature changes in the pulp chamber during polymerization of lightcured pulp- capping materials by using a VALO LED light curing unit at different curing distances. Dent Mater 2014;33(6): 764-769.

23.Al-Qudah AA, Mitchell CA, Biagioni PA, Hussey DL. Thermographic investigation of contemporary resin-containing dental materials. J Dent 2005;33:593-602.

24.Tosun G, Usumez A, Yondem I, Sener Y. Temperature rise under normal and cariesaffected primary tooth dentin disks during polymerization of adhesives and resincontaining dental materials. Dent Mater 2008;7(3): 466-470.
25.Kahvecioglu F, Tosun G, Ulker HE. Intrapulpal Thermal Changes during Setting Reaction of Glass Carbomer ${ }^{\circledR}$ Using Thermocure Lamp. BioMed Res Int 2016 doi: 10.1155/2016/5173805.

26.Khodadadi, E, Soraya K, Mahdiyeh A. Comparison of Surface Hardness of Various Shades of Twinky Star Colored Compomer Light-cured with QTH and LED Units. Electron Physician 2016;8(5):2355-2360.

27.Cagidiaco MC, Ferrari M, Vichi A, Davidson CL. Mapping of tubule and intertubule surface areas available for bonding in Class V and Class II preparations. J Dent, 1997;25(5):379-389.

\section{Corresponding Author}

Halenur Altan

Department of Pediatric Dentistry,

Gaziosmanpasa University, Tokat, Turkey

Postal Code: 60100

Phone: +90 5057253376

E-mail: halenuronat@gmail.com 